\title{
Managing your Health: Criminal Legal Aspects under the Legislation of Russia
}

\section{Sumachev $\mathrm{AV}^{*}$}

Doctor of law, Professor of Criminal Law and Criminal Procedure, Ugra State University, Russia

*Corresponding author: Alexey Vitalievich Sumachev, Doctor of Law, Professor of the Criminal Law and Criminal Procedure, Ugra State University, 628012, Khanty-Mansiysk, Russia, Tel: 8-922-478-71-22; Email: alekssumachev@mail.ru
Research Article

Volume 4 Issue 3

Received Date: July 21, 2021

Published Date: August 24, 2021

DOI: $10.23880 / a b c a-16000194$

\section{Abstract}

The article notes that the disposal of one's health can be considered as consent to harm to one's health by a third person and as causing physical harm to oneself (self-harm). In particular, the article analyzes the importance of consent to harm to health from third parties during medical intervention; donation; in the process of sports; during the production of a scientific experiment; when applying security measures to certain categories of citizens; when using the disciplinary power of parents to children, etc. The question of the responsibility of a person when self-mutilation on his part acts as a way of committing another crime is also considered. Accordingly, the rules for the qualification of criminally punishable acts of the fact of consent to the disposal of one's health are proposed. Along with this, it is noted that for cases when the implementation of a private interest (or consent) the acts do not exclude criminality or do not act as a constructive sign of a crime, it (private interest) should be taken into account when assigning punishment as a mitigating or aggravating circumstance.

Keywords: Human Health; Consent; Causing Harm; Criminal Legal Assessment of Acts; Criminal Liability

\section{Introduction}

The right to dispose of one's health (bodily integrity) can be considered in two aspects: as consent to harm to one's health by a third person and as causing physical harm to oneself (self-harm). The greatest controversy in the theory of criminal law is the question of the influence of consent when causing harm to health by third parties. So, at one time, Foynitsky IY, et al. [1] noted that “... injuries inflicted with the consent of the victim are not criminal, because the refusal of the benefit of bodily integrity is possible". Regarding this problem, Tagantsev NS, et al. [2] wrote: "Consent destroys responsibility in all those cases where the main role is played not by physical suffering, but by moral, violence against a person, violation of personal inviolability: it is impossible to allow criminal liability of a person who tore someone by the ears or hit him on the back, as soon as he did it at the request or with the permission of the victim. Consequently, there remain more serious injuries to the body injury, health disorder". Thus, the criterion for distinguishing between criminal and non-criminal encroachment on the bodily integrity of Tagantsev NS, et al. [2] determined based on the difference between the moral and physical orientation of the act. In cases of encroachments on bodily integrity for the purpose of causing moral suffering, consent destroys the criminality of the act. If the purpose is different causing physical suffering-the act should be recognized as criminal. Although Tagantsev NS, et al. [2] himself did not recognize this thesis as absolute, citing as an argument the actions of a doctor in the process of blood transfusion, conducting scientific experiments and other such similar actions.

Scientists of the Soviet period also ambiguously approached the solution of this problem, primarily because the harm to health (bodily injuries) can be different in their severity. Thus, I. I. Slutsky spoke about the criminality of causing serious bodily injuries [3]; Ya Nemirovsky E, et al. [4]; Zhizhilenko AA, et al. [5] about the absence of illegality 
when causing them with consent; Piontkovsky AA, et al. [6]; Dubovets PA, et al. [7]; Zagorodnikov NI, et al. [8] linked crime (non-criminality) those based on the social usefulness or harmfulness of the purpose of causing serious bodily harm. A similar position is taken by Kruglikov LL. et al. [9]. In particular, he writes: "The consent of a person to cause harm to his health does not exclude the criminal liability of the causer, with some exceptions (lawful medical intervention; participation in sports competitions related to physical contact; participation in an experiment)". Borodin SV, et al. [10], also spoke about the punish ability of causing harm with the consent of a person, except for cases of transplantation of human organs (tissues). This situation persists to the present time.

\section{Materials and Methods}

The main source for writing this article is the current Criminal Code of the Russian Federation, as well as the materials of monographic research and journal publications. In the course of the research, the main methods of cognition were used: problem-chronological, logical and systematic. The use of logical and systematic methods made it possible to integrate scientific views into the criminal law doctrine and formulate conclusions on the problems posed in the article.

\section{The Criminal-Legal Meaning of the Disposal of One's Health}

Belyaev NA, et al. [11]; Kovalev MI, et al. [12]; Martsev AI, et al. [13] refer to criminal acts only cases of causing serious or moderate harm to a person's health with his consent. They see the justification of their position in the existence of the institution of private prosecution, according to which, causing minor harm to health (minor bodily injuries) is punishable only on the complaint of the victim. So, Martsev AI, et al. [13] notes that "... in relation to acts that cause physical (bodily) harm to a person, it can be caused in an amount not exceeding that established for crimes for which prosecution can be terminated at the initiative of the victim". A practically similar point of view is expressed by Kuznetsova $\mathrm{NF}$, et al. [14]: "In the case of deprivation of life and causing any, except light, harm to health, the consent of the victim has no legal significance". However, he immediately notes: "The attribution of causing minor harm to health and insults to the cases of private prosecution does not mean the consent of the victim to such actions, but his refusal from the possible criminal prosecution of his abuser for one reason or another" [14].

So, causing serious or moderate harm to health, even with the consent of a person, should be recognized (and is recognized) as criminal. Regarding the impossibility of causing minor harm to health with the consent of a private person, we agree with the opinion of Belyaev NA, et al. [11]; Kovalev MI, et al. [12]; Martsev AI, et al. [13]; Kuznetsova NF, et al. [14]. But here it is worth making a few clarifications. In this regard, the last two positions seem to be fairer for us for a number of reasons. So, it is very difficult to justify the inviolability of causing even slight harm to a person's health with his consent. In this regard, it is advisable to shift the focus from the material grounds of such justification to the formal moments provided for by the legislation of the criminal cycle. In particular, it can be assumed that if the legislator has traditionally linked and connects the initiation of criminal prosecution for causing minor harm with the clearly expressed will of a private person, then this rule can also be transferred to the exclusion of criminality of an act expressed in causing such harm with the consent of a person. But here we will once again point out the validity of the statement of Kuznetsova NF, et al. [14] that the nature of causing harms with consent is not identical with the legal nature of initiating criminal prosecution. In the first case, the act is not criminal at the time of its commission; in the latter case, the crime has actually been committed and the will of the victim is manifested only when deciding whether to initiate criminal prosecution (refusal of it).

At the same time, individual acts of causing harm to health with the consent of a person may exclude the criminality of the act. Such circumstances occur in cases of surgical medical intervention, donation, sports, etc. Therefore, the onset of responsibility for causing physical harm with the consent of a person is not unconditional. Moreover, it requires clarification of the fact that here we are talking about the so-called "pure" cases of encroachments on bodily integrity, i.e. acts provided for in Chapter 16 of the Criminal Code of the Russian Federation (hereinafter-the Criminal Code of the Russian Federation) "Crimes against life and health". If causing harm to health with the consent of a person acts as a way of committing another crime, the criminal legal meaning of such consent changes. Here, consent can influence the qualification of criminally significant acts (including crimes), and in some cases, the imposition of punishment.

\section{Own Research of the Question of the Criminal- Legal Significance of the Realization of a Private Interest (Expressed In Behavioral Acts) in the Qualification of Criminally Significant Cases of Harm to Health}

The realization of the patient's private interest in providing him with medical care has different criminal-legal significance. Compliance with the conditions for the legality of providing medical care (defined, as a rule, in medical regulations) excludes cases of causing serious or moderate harm to health from the number of criminally punishable. So, 
for example, according to the testimony of medical workers, the fracture of several ribs during the production of direct heart massage is evidence of conscientious assistance to the patient, his salvation. These actions are evaluated according to the rules of extreme necessity and reasonable risk (Articles 39, 41 of the Criminal Code of the Russian Federation). If there was an error of the doctor due to his negligent or unfair attitude to his professional duties and the act caused serious harm to the patient's health, the act should be qualified under part 2 of Article 118 of the Criminal Code of the Russian Federation. An important condition for such qualification is the patient's consent to provide him with medical care (again, with the exception of cases of medical intervention (treatment) determined by the legislation of Russia against the will of the patient). The infliction of light and moderate harm to health in such cases excludes the criminal liability of doctors.

The private interest of a healthy person who has applied for medical care in healthcare institutions also has an important criminal legal significance. The presence of desire (consent) artificial insemination and implantation of an embryo, artificial termination of pregnancy, medical sterilization, donation of blood and its components, transplantation of human organs and (or) tissues, conducting a medical experiment excludes criminal liability of a doctor. If, as a result of such medical manipulations, serious harm is caused to the patient's health, which is characterized by signs of non - intended harm (for example, plastic surgery of the face caused vision loss; taking blood from a donor-blood poisoning, etc.), this gives reason to speak about the careless form of the fault of the harm-causer (medical worker). Such acts should also be qualified under Part 2 of Article 118 of the Criminal Code of the Russian Federation. The lawful conduct of an artificial termination of pregnancy, along with the consent of the patient, requires that the doctor has a higher medical education of the appropriate profile, otherwise it should be about the responsibility of the culprit under Part 1 or 3 of Article 123 of the Criminal Code of the Russian Federation. The lack of consent determines the qualification of the actions of a doctor who has an education of the appropriate profile, according to Article 111 of the Criminal Code of the Russian Federation.

The presence of the consent of the patient (both healthy and sick) to commit manipulations of a medical nature against him, but the absence of an appropriate license from the harm-causing person engaged in private medical practice or private pharmaceutical activity, allows us to speak about the presence of signs of a crime under part 1 of Article 235 of the Criminal Code of the Russian Federation. It should be noted that the legislator in part 1 of Article 235 of the Criminal Code of the Russian Federation uses the phrase "causing harm to health", without specifying the degree of its severity. Therefore, from the standpoint of the law, harm to health can be of any severity.

The infliction of serious or moderate harm to health during sports excludes criminal liability of the harm-causer if he complies with the rules of a particular sport. Causing serious or moderate harm to health in violation of the rules of sports competitions should be regarded as follows. Thus, in accordance with the current criminal law, an intentional violation of the rules of sports competitions, which entailed causing serious harm to health through negligence, should be qualified under art. 118 of the Criminal Code of the Russian Federation, solving the problem of mitigating punishment not at the stage of qualification of the act, but in the process of assigning punishment. At the same time, the athlete is subject to criminal liability only for intentional violation of the rules of sports competitions that caused serious harm to the opponent's health. Accordingly, if there was a careless violation of the rules of sports competitions, as a result of which serious harm was caused to the opponent, it is not necessary to raise the question of criminal liability of the harm-causer.

A slightly different legal situation arises in cases of serious harm to health during the production of a scientific experiment (involving physical isolation from society), when security measures are applied to certain categories of citizens, expressed in their temporary placement in a safe place, as well as the use of the disciplinary power of parents to children. In all these cases, it is necessary to talk about the criminal responsibility of the perpetrators. So, if, as a result of a scientific experiment involving the isolation of a person from society, a person-object of research has a mental disorder (serious harm), the head of the experiment should be held responsible under part 2 of Article 118 of the Criminal Code of the Russian Federation. The reference to a reasonable risk is not applicable in this case, because the private interest (consent) of the experimental person extends to the restriction of physical freedom, but not to causing harm to his health. This rule fully applies to the situation of causing serious harm to health when applying security measures, since the isolated person agrees to temporarily place him in a safe place, but not to cause harm to health in any way.

The use of the disciplinary power of the parents, which resulted in causing serious harm to the child's health due to negligence, additional qualification under Article 118 of the Criminal Code of the Russian Federation is not required. This act is covered by Article 156 of the Criminal Code of the Russian Federation. If the harm is caused intentionally, the act forms a combination of Article 156 of the Criminal Code of the Russian Federation and the corresponding article of Chapter 16 of the Criminal Code of the Russian Federation (paragraph " b " of part 2 of Article 111 or paragraph "in" 
Part 2 of Article 112 of the Criminal Code of the Russian Federation on the basis of "in relation to a minor or other person who is obviously in a helpless state for the guilty person").

Recently, the facts of the creation of religious and other public associations whose activities involve violence against citizens, self-harm or harm to human health with their consent have become widely known. Thus, according to Galiakbarov RR, et al., "The facts of causing such harm are closely related to the ideas of physical self-torture and asceticism, which is the basis of a number of creeds. Followers are often required to suffer physically" [9]. Self-harm or with the consent of a person, if such activity is carried out on behalf of, as well as within the framework of the activities of a religious or public association, it is considered criminal not only to create and manage such an association, but also to participate in it (Article 239 of the Criminal Code of the Russian Federation). Consequently, the private interest of a person associated with his participation in the activities of such a religious association can act as a constructive sign of the corpus delicti provided for in Part 3 of Article 239 of the Criminal Code of the Russian Federation on the basis of "participation in the activities of the specified association". At the same time, if there was self-mutilation, the person should be held liable only under Part 3 of Article 239 of the Criminal Code of the Russian Federation. If the harm is caused by another ordinary member of the sect with the consent of a person, the harmer is liable under part of Article 239, as well as for intentionally causing serious or moderate harm to health (Article 111 or 112 of the Criminal Code of the Russian Federation). Intentional actions of such persons that caused minor harm to health are covered by Part 2 of Article 239 of the Criminal Code of the Russian Federation.

There is a special question about the responsibility of a person when self-mutilation on his part acts as a way of committing another crime. The current criminal legislation defines two such cases provided for by Article 328 of the Criminal Code of the Russian Federation (in which selfmutilation can act as one of the ways to evade military and alternative civil service) and Article 339 of the Criminal Code of the Russian Federation (in which self-mutilation can act as a constructive sign of the objective side of the act). Naturally, a person who has caused harm to his health is liable only under these articles of the Criminal Code of the Russian Federation.

\section{Results}

Thus, if serious or moderate harm to human health is caused by a third person with the consent of the first, such an act should be qualified according to the rules of complicity in crimes with a special subject and the corresponding articles of the criminal law providing for liability for intentional infliction of serious (Article 111 of the Criminal Code of the Russian Federation) or moderate (Article 112 of the Criminal Code of the Russian Federation) harm to health. In cases where the implementation of a private interest (or consent) the acts do not exclude criminality or do not act as a constructive sign of a crime, it (private interest) should be taken into account when assigning punishment as a mitigating or aggravating circumstance.

\section{References}

1. Foynitsky IY (1907) Course of criminal law. The Part is Special. Personal and property encroachments. $5^{\text {th }}$ (Edn.), pp: 442.

2. Tagantsev NS (1994) Russian criminal law. Lectures: General part 2(1): 380 .

3. (1960) Soviet criminal law. The General Part. Leningrad Publishing House, pp: 587.

4. Ya Nemirovsky E (1926) Soviet criminal law. The parts are general and special. $2^{\text {nd }}$ (Edn.), pp: 368.

5. Zhizhilenko AA (1927) Crimes against the person, pp: 140.

6. Piontkovsky AA (1961) The doctrine of a crime under Soviet criminal law, pp: 666.

7. Dubovets PA (1969) Responsibility for bodily injuries under Soviet criminal law, pp: 160.

8. Zagorodnikov NI (1969) Crimes against Health, pp: 168.

9. Kruglikov LL (1999) Criminal law of Russia. A special part: A textbook for universities, pp: 799.

10. Kudryavtsev VN, Naumov AV (1997) Russian criminal law. Special, pp: 496.

11. Belyaev NA (1968) The course of Soviet criminal law, pp: 648.

12. Kovalev MI (1997 Criminal law. General part: Studies for universities, pp: 503.

13. Martsev AI (1998) Criminal Law of the Russian Federation. Omsk: Law Institute of the Ministry of Internal Affairs of Russia, pp: 366.

14. Kuznetsova NF (2002) The course of criminal law. The general part: The doctrine of crime. Textbook for universities 1: 611 . 